\title{
Pembelajaran 3D Printing sebagai metode perancangan produk kostum Studi Kasus: industri cosplay
}

\author{
Putri Anggraeni Widyastuti ${ }^{*}$
}

Program Studi Desain Produk, Universitas Esa Unggul, Jakarta, Indonesia

\begin{abstract}
Currently costume products can be enjoyed not only for film, drama or theater productions but for people as a form of appreciation to the fictional and non-fictional characters in two dimensions. Cosplay (abbreviation of a word: costume and play) in Indonesia has developed into a industry within a period of 15 year due customer needs. Even as cosplayer (people who cosplay) who has long been active in cosplaying, develop tecniques and the use of the material in process of designing cosplay costumes until introduce profession cosmaker (an abbreviation of costume maker). They have needed experience to cultivate material and technique that support skill of cosplayer and cosplayer craft's to design costume for custom or mass, like $3 D$ printing. This technique have been used to simplify the design process costume because efficiently and with more having the accuracy of finite dimensionnal produce of the successive visual better. For this reason, this research is needed with the aim that $3 D$ printing can be a part of and enrich the design of costume products so that it can take part of basic in learning basic education design. This purpose will achieve through the qualitative study in a series of stage of the methodology grounded theory to declare that 3D printing can be a part in learning basic education design to answer the challenges the industrial revolution 4.0 through phenomenology approach to phenomena cosplay in Indonesia for 15 year who experienced by writer directly design cosplay costume.
\end{abstract}

Key words: 3D printing, Indonesia cosplay industry, method of design, learning, costume product

\begin{abstract}
Abstrak
Saat ini produk kostum dapat dinikmati tak hanya untuk produksi film, drama atau teater tapi juga untuk semua orang sebagai bentuk bentuk apresiasi dirinya terhadap karakter fiksi maupun non-fiksi bernarasi dua dimensi. Cosplay (singkatan dari kata costume, dan kata play) di Indonesia juga telah berkembang menjadi industri dalam jangka 15 tahun karena adanya kebutuhan konsumen. Bahkan cosplayer (sebutan pelaku cosplay) yang telah lama berkiprah dalam cosplay mengembangkan teknik dan penggunaan material dalam proses perancangan produk kostum cosplay hingga akhirnya melahirkan profesi cosmaker (singkatan dari costume maker). Diperlukan pengalaman mengolah material dan teknik yang didukung keterampilan craft cosplayer dan cosmaker dalam merancang kostum untuk custom atau massal, seperti 3D printing. Teknik ini mempermudah proses perancangan kostum karena efisien dan memiliki keakuratan dimensi hingga menghasilkan visual yang lebih baik. Untuk itulah diperlukan penelitian ini dengan tujuan agar 3D printing ini dapat menjadi bagian dan memperkaya perancangan produk kostum sehingga dapat menjadi bagian dalam pembelajaran pendidikan dasar desain. Tujuan ini akan tercapai melalui penelitian kualitatif dalam tahapan metode penelitian grounded theory untuk menyatakan 3D printing dapat menjadi bagian dalam pembelajaran pendidikan dasar desain untuk menjawab tantangan revolusi industri 4.0 melalui pendekatan fenomenologi terhadap fenomena cosplay di Indonesia sendiri selama 15 tahun ini yang dialami oleh penulis yang terlibat secara langsung merancang kostum cosplay.
\end{abstract}

Kata kunci: 3D printing, industri cosplay Indonesia, metode perancangan, pembelajaran, produk kostum

\section{Pendahuluan}

Kostum merupakan produk yang dihasilkan oleh desainer kostum untuk dikenakan artis atau aktor dalam pementasan atau pertunjukan baik di teater, film, atau drama sekalipun. Sayangnya pemikiran tersebut tidak sesuai dengan munculnya komunitas cosplay di Jakarta tahun 2004. Komunitas ini terbentuk adanya acara cosplay, di mana cosplayer saling bertemu satu dengan lainnya memamerkan kostum buatannya sesuai dengan karakter non-fiksi atau fiksi dua dimensi. Mereka mewujudkan bentuk

\footnotetext{
* Corresponding author e-mail : putri.anggraeni@esaunggul.ac.id
} 
tiga dimensi melalui kostum pada karakter dua dimensi tersebut. Tak hanya kostum, mereka juga membuat senjata, helm, sepatu, atau alat pendukung pertunjukan lainnya (yang disebut dengan prop) (Gambar 1).

Saat ini acara cosplay dapat ditemui dengan mudah pada tempat-tempat di Indonesia setiap tahunnya. Bahkan selama 15 tahun ini terjadi perubahan produk cosplay (kostum, tata rambut, aksesoris, tata rias, dan senjata, serta prop) yang dibuat oleh cosplayer menggunakan tangan dan material sederhana, berkembang menggunakan beragam teknik dan kombinasi bahan. Kondisi ini berbeda di tahun 2004. Saat itu, cosplayer mengenakan kostum seadanya tapi tetap kreatif menggunakan material melalui pengolahan teknik seadanya. Perubahan produk cosplay ini terdokumentasi dengan jelas bersamaan dengan media promosi acara cosplay di Indonesia, mulai dari majalah hingga bentuk digital pada media sosial, yang dapat terlihat dalam analisa pemetaan diakronik iklan acara Cosplay di Jakarta pada majalah "Animonster" (majalah yang membahas kebudayaan popular Jepang) (Gambar 2).

Dari Gambar 2 tersebut, dapat disimpulkan bahwa media digunakan untuk mempromosikan acara. Tak hanya itu media (baik cetak atau digital) mendokumentasikan acara cosplay setiap tahunnya. Biasanya pada acara cosplay, cosplayer tidak hanya memamerkan kostum tapi biasanya melakukan pertunjukan selama 3 menit per peserta didukung dengan narasi dan lagu yang sesuai dengan karakter yang dibawakan di atas panggung. Hal tersebut disebut cosplay competition.

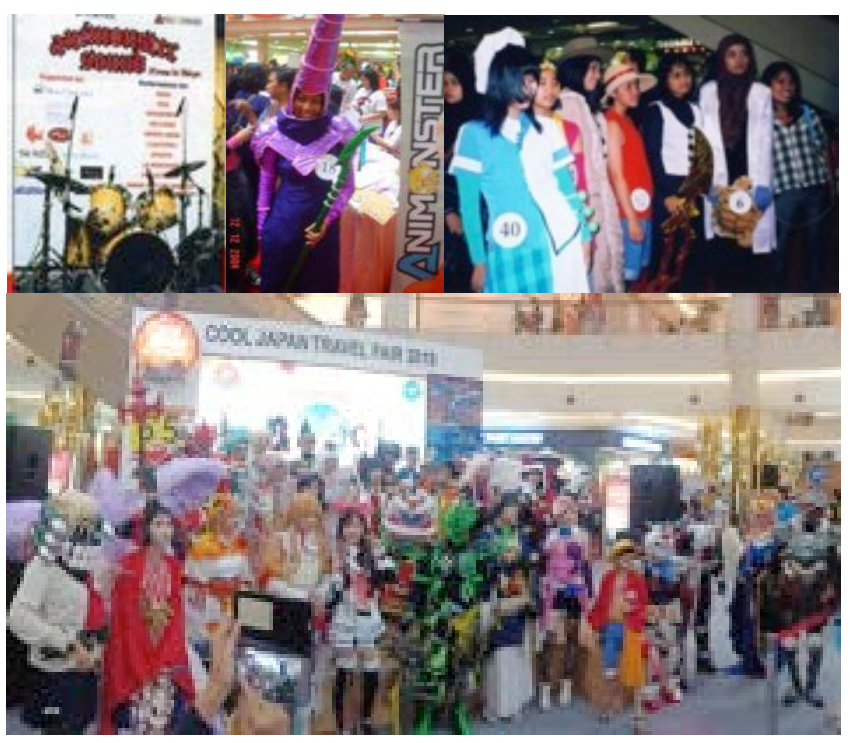

Gambar 1. Suasana Acara Cosplay Tahun 2004 dan 2019 (sumber: Putri Anggraeni Widyastuti, 2019)
Makin banyaknya minat cosplayer di Indonesia, membuat rentang waktu pertunjukan untuk peserta dalam lomba tersebut tidak memungkinkan sehingga lahirlah istilah coswalk (atau disingkat dengan cosplay walk). Dalam lomba ini atau pun tidak, biasanya cosplayer tetap diberikan kesempatan untuk mempertunjukan aksinya dengan musik yang disediakan oleh panitia di atas panggung.

Meningkatnya permintaan cosplay setiap tahunnya dalam jangka waktu 15 tahun belakangan ini mendorong lahirnya profesi baru, yang disebut cosmaker (singkatan dari cosplay maker). Profesi ini lahir dari cosplayer berpengalaman membuat produk cosplay dalam acara cosplay. Mereka membuka jasa pembuatan kostum bagi para klien yang ingin dengan mudah mendapatkan produk untuk ber-cosplay saat acara cosplay, tanpa harus bersusah payah membuat kostum. Klien dapat memesan produk cosplay secara custom kepada cosmaker berdasarkan kebutuhan dan spesifikasi terstentu. Ada juga produk cosplay dibuat massal secara industrial. Sayang, tak semua cosmaker di Indonesia memiliki kemampuan membuat kostum yang sama. Biasanya mereka memiliki kemampuan spesifikasi teknik tertentu dalam membuat kostum dengan material yang berbeda dengan cosmaker lainnya, dari teknik manual hingga digital sekalipun. Hal ini karena ada material dan motif yang tak tersedia di pasar material, sehingga cosplayer atau cosmaker menggunakan teknik digital seperti cetak kain. Mereka juga menggunakan teknik 3D printing untuk membuat bagian pelengkap dari kostum karakter tersebut atau pun satu penuh kostum demi mewujudkan karakter fiksi dan non-fiksi dua dimensi bernarasi tersebut entah itu dari Eropa, Asia ataupun Amerika. Bahkan sejak cosplayer Indonesia mengikuti acara cosplay internasional (World Cosplay Summit/WCS) di Jepang setiap tahunnya, dan meraih juara pertama di tahun 2017 ini, produk cosplay buatan cosplayer atau cosmaker Indonesia pun makin diakui di kancah internasional. Sebagai bukti para cosmaker Indonesia sudah menerima pesanan produk kostum dari luar negeri.

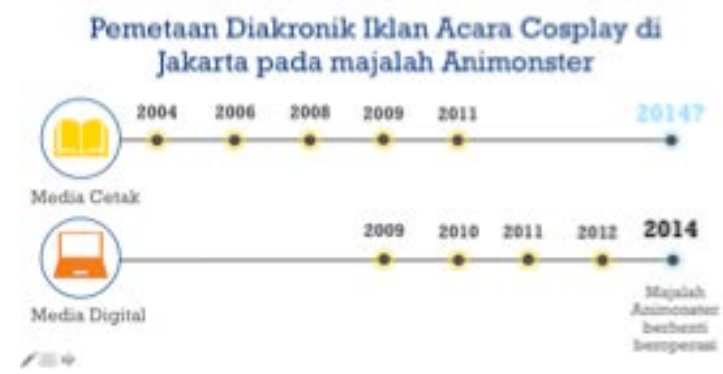

Gambar 2. Analisa Pemetaan Diakronik Iklan Acara Cosplay di Jakarta pada majalah Animonster (sumber: Putri Anggraeni Widyastuti, 2018) 
Oleh karena itulah pada penelitian ini akan dibahas seberapa penting dan potensialkah teknik 3D printing ini agar dapat menjadi bagian dalam pembelajaran metode perancangan produk kostum sehingga dapat memperkaya pengetahuan dalam pendidikan dasar desain khususnya desain produk itu sendiri.

Dari uraian di atas diperoleh sebuah rumusan masalah, yakni bagaimana teknik 3D printing dapat dijadikan bagian dari pembelajaran proses perancangan produk kostum dalam pendidikan dasar desain, dengan studi kasus metode perancangan produk kostum industri cosplay Indonesia? Tujuan penelitian ini adalah agar teknik 3D printing dapat menjadi bagian dalam pembelajaran metode perancangan produk kostum agar dapat memperkaya dan memperbaharui pengetahuan dalam pendidikan dasar desain khususnya desain produk. Hasil penelitian ini pun nantinya dapat dimanfatkan untuk peneliti selanjutnya yang akan mengambil objek penelitian yang sama mengenai metode perancangan produk khususnya kostum, serta dapat mengaplikasikannya pada proses perancangan tersebut untuk membuat kostum dengan memanfaatkan teknik 3D printing sehingga nantinya dapat menjadi bekal ilmu bagi mahasiswa maupun masyarakat untuk berwirausaha dalam merancang produk.

\section{Bahan dan metode}

Pengertian pembelajaran sendiri adalah proses interaksi peserta didik dengan pendidik dan sumber belajar dalam suatu lingkungan belajar. Pembelajaran merupakan bantuan yang diberikan pendidik agar dapat terjadi proses perolehan ilmu dan pengetahuan, penguasaan kemahiran dan tabiat, serta pembentukan sifat dan kepercayaan pada peserta didik. Dengan kata lain, pembelajaran adalah proses untuk membantu peserta didik agar dapat belajar dengan baik. Sementara pembelajaran dalam pendidikan dasar desain khususnya desain produk lebih menggunakan pendidikan dasar Josef Albers (Masri \& Pasaribu, 2018). Seperti yang dikatakan oleh Andry Masri dalam tulisannya "Tinjauan Craft di Pendidikan Tinggi”, bahwa secara esensial, pengajaran Josef Albers menganjurkan elaborasi praktika daripada teori sebagai asimilasi pasif konsep, tidak berbeda dengan pengajar-pengajar lain. Ia malah memberikan tugas untuk menguji kapasitas resistensi material, reaksinya terhadap tegangan dan kelenturan secara simultan, perakitan, titik-titik lemah material, dan dengan cara demikian memungkinkan mahasiswa untuk menilai kemampuan dan batas kemajuran material itu (Masri
\& Pasaribu, 2018). Pengolahan bentuk berkaitan erat dengan pengalaman langsung dan ciri-ciri khas masing-masing bahan. Jadi yang diutamakan adalah disini pengalaman langsung terhadap material dan teknik yang menyesuaikan teknologi yang ada. Salah satunya adalah 3D printing yang muncul pada Revolusi Industri 4.0 ini. Oleh karena itulah diharapkan pembelajaran 3D printing itu dapat menjadi bagian dalam metode perancangan produk kostum. Umumnya cara kerja 3D printing ini dilakukan dengan membuat model menggunakan software computer-aided design (CAD) atau sejenisnya, lalu mesin 3D printing mengikuti model software untuk menentukan bagaimana membentuk objeknya dengan "mencetak" potongan melintangnya layer demi layer (Akmal, 2019).

Aileen Abercrombie dalam bukunya, "Performance Costume Design at the New York Public Library for Performing Arts" mengatakan bahwa ada 2 cara untuk membahas desain kostum itu sendiri yakni "cara berpakaian" dan "sejarah desain kostum”. "Cara berpakaian" mengontekstualisasikan cara orang berpakaian dalam periode waktu mereka karena lingkungan, jenis kelamin, posisi, kendala ekonomi, dan sikap. Pada dasarnya ini berhubungan dengan pendekatan antropologis untuk desain kostum. Sementara yang lain, mempelajari "sejarah desain kostum,” yakni memeriksa cara perancang kostum menafsirkan cara berpakaian dalam periode waktu mereka yang terdiri dari sejarah profesi dan professional. Desainer Kostum berkolaborasi dengan beragam profesional yang luar biasa dari disiplin ilmu lain selama proyek tertentu. Bergantung pada bahan sumbernya atau projeknya, contoh perancang kostum dapat mewawancarai petugas polisi atau tokoh agama untuk mempelajari adat istiadat dan "cara berpakaian" kelompok tersebut (Abercrombie, 2015). Simon Travers Spencer dan Zrida Xaman pada bukunya The Fashion Designer's Directory Shape and Style mengatakan bahwa pada umumnya proses metode perancangan kostum ini tidak berbeda jauh dengan proses perancangan fashion dalam mendesain koleksi busana yang dimulai dengan melakukan penelitian terhadap objek atau tema desain. Barulah selanjutnya memvisualisasikan objek tersebut dan material yang digunakan pada sebuah papan suasana (mood board). Pada tahapan ini akan muncul warna-warna dan tekstur yang akan digunakan untuk dijadikan sebuah landasan dalam pengembangan desain yang harus memahami proposi tubuh. Setelah itulah masuk pada tahapan produksi seperti membuat pola, menggunakan teknik jahit atau teknik lainnya yang dapat mengkontruksi busana tersebut sesuai dengan desainnya (Travers-Spencer \& Zaman, 2008). 
Penelitian ini menggunakan metode kualitatif dengan pendekatan grounded theory. Penelitian grounded theory diawali dengan pengamatan terhadap fenomena sebagai a way of looking at things bagi gejala menampilkan diri untuk melukiskan melalui pemahaman metode perancangan produk cosplay dalam industri cosplay Indonesia pada perubahan produk cosplay buatan cosmaker melalui pendekatan secara inderawi sebagai cosplayer dan cosmaker pada acara cosplay sejak tahun 2004. Dari data ini maka dapat diperoleh kategori kostum apa saja yang dapat menggunakan teknik 3D printing sehingga nantinya menghasilkan hipotesa kerja yang dapat mendukung sebuah kesimpulan akhir. Penulis pun bertemu dengan beberapa cosmaker Indonesia yang juga cosplayer yang memiliki beberapa ciri tertentu dalam memproduksi produk cosplay dengan menggunakan material dan teknik tertentu sesuai dengan perkembangan jaman.

Pengungkapan keberadaan 3D printing dalam proses perancangan produk kostum pada industri cosplay di Indonesia, dapat ditelusuri dengan mengikuti pengamatan visual, pengalaman inderawi, dan penelusuran aspek-aspek yang terkait dalam proses tersebut, sekaligus memperoleh pemahaman atas objek penelitian untuk memperteguh makna. Proses perancangan kostum cosplay dialami oleh penulis saat mencoba mengaplikasikan teknik dan pengolahan material (Widyastuti, Pertiwi, \& Huddiansyah, 2019). Umumnya dalam proses perancangan cosplay terdiri dari beberapa tahapan, seperti penentuan karakter dengan mencari referensi gambar tampak depan, belakang, dan samping. Referensi ini dicetak berwarna pada kertas sehingga membentuk moodboard seperti yang dilakukan dalam proses perancangan produk fashion pada umumnya. Kemudian setelah itu ditentukan material yang akan digunakan pada karakter dua dimensi fiksi atau nonfiksi tersebut. Pada tahapan ini terjadi tahapan eksplorasi material yang akan digunakan untuk membangun konstruksi kostum. Barulah tahapan selanjutnya membuat pola (pemolaan) sebelum memotong material. Biasanya cosplayer yang mahir dan berkutat pada material berjenis busa seperti busa kasur atau busa hati (eva foam) yang pada umumnya tidak harus menggunakan pola, karena sudah terbiasa membuat pola langsung pada material, dan menempel bagian tersebut menggunakan lem Aibon. Sementara untuk material kain dan sejenisnya melalui tahapan pemolaan dan pemotongan serta penjahitan. Dalam tahapan pemolaan, biasanya cosplayer atau cosmaker mengukur terlebih dahulu tubuh manusia yang mengenakan kostum ini, entah cosplayer sendiri atau klien. Pada metode perancangan kostum cosplay, cosplayer membuat proporsi, karena biasanya karakter dua dimensi fiktif atau non-fiktif bernarasi ini tak jarang memiliki ukuran anatomi yang berbeda dengan ukuran anatomi manusia, sehingga diperlukan proporsi agar kostum yang dihasilkan pun terkesan seimbang dan tidak terlihat aneh dalam perancangan produk kostum secara ukuran.

Tahapan proses perancangan produk kostum cosplay di atas ini bisa dikategorikan dalam kategori kostum non-armor (Gambar 3). Istilah ini sebenarnya sudah ada dalam dunia cosplay di Indonesia di mana kostum non-armor ini sebagian besarnya menggunakan material kain. Sementara ada pula istilah kostum armor di mana kostumnya sebagian besar menggunakan material di luar kain seperti busa hati, besi, kayu, dan lainnya. Istilah kostum armor dan kostum non-armor inilah yang membedakan spesifikasi kemampuan para cosmaker di Indonesia.

Penggunaan teknik 3D printing dalam industri cosplay sendiri sebenarnya biasa dilakukan di luar negeri. Dalam buku Cosplay: The Fantasy of Role Play karya Lauren Orsini, dijelaskan bahwa Natasha Spokish dengan nama cosplay-nya Vinding Smalls membuat prop atau pun kostum menggunakan 3D printing yang dia desain sendiri dari karakter fiksi atau non-fiksi dua dimensi (Orsini, 2015). Dengan mengunakan 3D printing ini, ia pun dapat merancang kostum, prop, atau aksesoris lainnya dengan lebih cepat dan akurat. Bahkan untuk membuat satu kostum lengkap menggunakan teknik 3D printing ini, ia harus membuat per bagian karena kekurangan dari dimensi dari mesin 3D printing itu sendiri yang tidak besar. Namun demikian untuk menggunakan teknik ini, cosplayer atau cosmaker harus mengguasai 3D modelling terlebih dahulu.

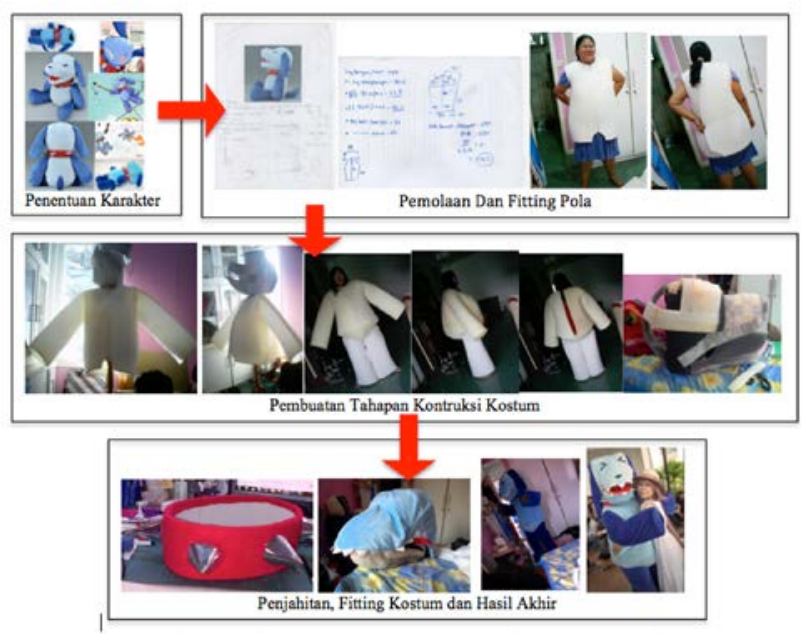

Gambar 3. Tahapan proses perancangan produk kostum cosplay (sumber: Widyastuti, 2019) 


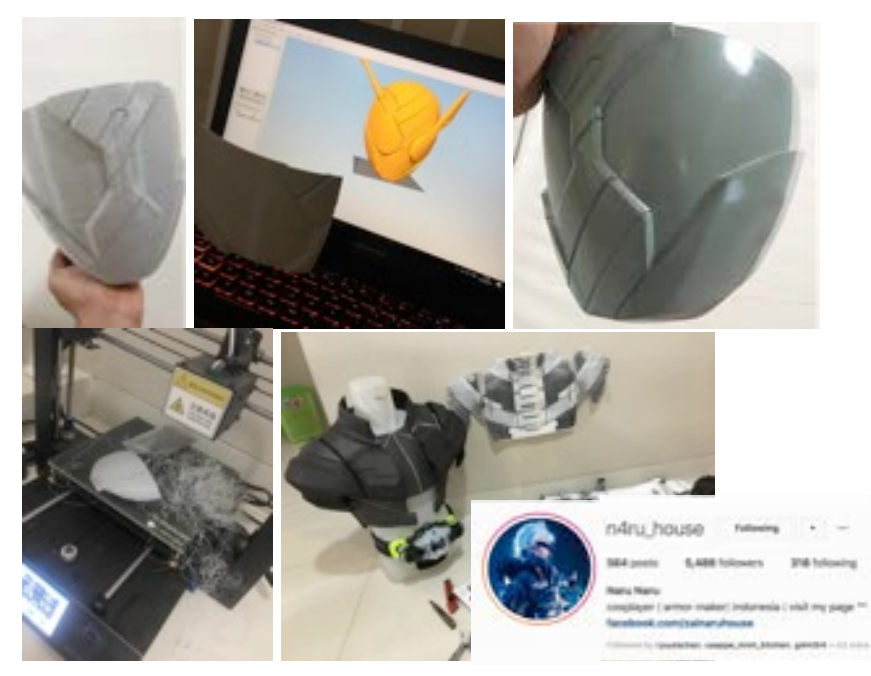

Gambar 4. Aplikasi 3D Printing pada proses perancangan kostum oleh Cosplayer Naru

(sumber: Widyastuti, 2019)

Sementara di Indonesia sendiri ada Naru, seorang cosplayer dan peserta WCS 2013 yang menekuni teknik 3D printing dalam proses perancangan kostumnya (Gambar 4). Sebagai cosplayer dan cosmaker, Naru mencoba teknik ini agar kostum yang dibuatnya lebih presisi dan memberi kesan rapih atau bersih untuk tekstur kostumnya. Dari wawancara dengannya, terungkap bahwa dari hasil eksplorasi material maupun teknik yang pernah ia lakukan, 3D printing-lah teknik yang dapat mencetak objek menjadi lebih presisi dibanding menggunakan material busa hati. Untuk mengolahnya pun dari tekstur kasar menjadi tekstur halus lebih mudah. Dari hasil cetakan 3D printing ini pun membuat dirinya lebih mudah mengamplas dan mendempul lalu kemudian mengecat cetakan tersebut. Ia pun dapat mencetak lebih banyak menggunakan teknik cetak tuang untuk memproduksi selanjutnya dengan presisi yang lebih baik dibandingkan dengan menggunakan busa hati yang memiliki karakter menyerap dibandingkan filament plastic untuk 3D printing (Widyastuti et al., 2019).

Sebelum menggunakan teknik ini pun, cosplayer harus belajar menggunakan software yang mendukung. Seperti halnya Ryancyd dan Naru, yang merupakan anggota cosplay Daikon Sky ini mencoba menggunakan teknik 3D printing. Hasilnya pun sudah pasti harus memerlukan proses trial and error agar dapat mendapatkan bentuk tiga dimensi yang memuaskan dan sesuai dengan bentuk badan. Sayangnya menurut Verde, seorang manager cosplay, profesi yang mengatur berlangsungnya kegiatan acara cosplay yang dilakukan oleh CosplayJakarta, koordinator komunitas cosplay ini pun mengatakan bahwa 3D printing ini memiliki kelemahan terutama di Indonesia, diantaranya selain harga mesinnya yang mahal, ditambah ketersediaan filament-nya yang masih terbatas sehingga penggunaannya pun belum tersebar dengan merata (Widyastuti et al., 2019).

Dari hasil penelitian grounded theory di atas maka ditemukan sebuah hipotesa kerja yakni: "Diperlukan sebuah analisis penggunaan 3D printing dalam metode perancangan produk kostum pada industri cosplay Indonesia ini agar terlihat seberapa penting dan potensialkah teknik ini digunakan sebagai bagian dalam pembelajaran metode perancangan produk kostum dalam pendidikan dasar desain khususnya desain produk."

\section{Hasil dan pembahasan}

Proses perancangan produk kostum pada industri cosplay Indonesia menggabungkan dua buah objek yang dapat dilakukan dengan cara mimesis. Mimesis sendiri adalah peniruan seutuhnya dari objek yang dipinjam. Cara ini bisa dibilang merupakan cara paling efektif dalam menyampaikan makna yang jelas. Kelemahan cara ini adalah nilai desain yang ditampilkan pun memiliki kualitas visual yang mungkin sangat rendah bahkan seolah-olah berkesan 'murah'. Namun demikian bukan berarti disini peran cosplayer atau cosmaker mengambil ide desain karakter dua dimensi lalu diakui sebagai miliknya. Tidak seperti itu, justru mereka berposisi sebagai pengrajin yang mewujudkan karakter dua dimensi atas pesanan custom. Namun bisa juga berposisi sebagai desainer dengan cara membuat karakter sendiri dalam bentuk dua dimensi bernarasi dan menghadirkannya dalam bentuk tiga dimensi melalui kostum, aksesoris dan lainnya.

Justru dengan cara mimesis inilah, maka cosplayer maupun cosmaker dapat menghadirkan secara visual melalui proses eksplorasi material yang digunakan dalam proses perancangan. Dengan adanya strategi visual ini pun menjadi sebuah aspek pendukung utama bagi cosplayer dalam melakukan pertunjukan di atas panggung pada sebuah lomba cosplay. Mereka bisa menghadirkan karakter 2 dimensi fiksi atau nonfiksi bernarasi ini dalam balutan kostum, aksesoris, tata rias, tata rambut, senjata ataupun alat panggung dalam bentuk 3 dimensi sesuai pesanan konsumennya secara custom melalui penghayatan karakter dengan pertunjukan di atas panggung yang diiringi dengan narasi dan musik pendukung. Dengan cara memesis ini maka strategi visual perancangan produk kostum pun dapat terwujud di dunia nyata dalam bentuk tiga dimensi, terutama di mata penonton atau pengemar karakter tersebut dalam sebuah acara cosplay. 
Dari hasil pendekatan secara fenomenologi terhadap proses perancangan produk kostum dalam industri cosplay Indonesia, maka didapat tahapan merancang kostum di antaranya adalah (1) mencari referensi karakter; (2) membuat moodboard; (3) menentukan material; (4) membuat pola; dan (5) eksplorasi material dan teknik. Tahap pertama, mencari referensi karakter. Cosplayer menentukan karakter yang akan diwujudkan kostumnya baik tata busana, tata rias, tata rambut, maupun senjata atau alat pendukung pertunjukan lainnya. Setelah itu ia harus mencari referensi karakter dari tampak depan, tampak samping dan tampak belakang untuk mengetahui detail motif dan material bahan yang digunakan. Yang kedua, membuat moodboard. Setelah referensi karakter didapat, maka visual karakter dari tampak depan, samping dan belakang dengan detail motif kostum tersebut disusun pada sebuah papan suasana lengkap dengan warna yang akan digunakannya. Selanjutnya menentukan material. Dari moodboard tersebut, dapat diperkirakan material apa yang sesuai yang dapat digunakan oleh cosplayer atau cosmaker untuk merancang kostum, aksesoris, senjata dan alat peraga lainnya. Dari material ini biasanya kostum yang akan siap lomba cosplay dan dikategorikan menjadi kostum armor dan kostum non-armor. Tahap berikutnya adalah membuat pola. Pada umumnya, cosplayer atau cosmaker membuat pola dasar dari sebuah kostum sebelum masuk menuju tahapan selanjutnya yakni membuat pecah pola kostum. Sebelum membuat pola, cosplayer atau cosmaker harus mengukur badan agar kostum yang dibuat proposional dan sesuai dengan karakternya. Tahapan terakhir adalah eksplorasi material dengan beragam teknik pengerjaan. Pada tahapan ini terjadi proses eksplorasi material sesuai dengan karakter dua dimensi yang dibangun dan juga material yang dipilih. Dalam satu karakter tidak selalu terdiri dari satu material yang sama, tapi juga terjadi kombinasi material dan teknik dalam satu proses pengerjaan kostum. Tergantung dari karakter dua dimensi yang dipilih oleh cosplayer itu sendiri.

Melihat tahapan yang dilakukan oleh cosplayer dan cosmaker dalam perancangan kostum pada industri cosplay di Indonesia, terdapat beberapa kemiripan, terutama dalam hal pendekatan eksplorasi material untuk menemukan keunikan pada visual sebuah produk. Andry Masri dalam tulisannya berjudul "Eksplorasi Material Sebagai Pendekatan Craft Pada Dunia Akademis”, mengatakan bahwa eksplorasi material adalah satu pendekatan berkreasi yang dilakukan oleh sebagian besar pendidikan tinggi desain (Masri \& Pasaribu, 2018). Pendekatan eksplorasi material ini merupakan salah satu metode pembelajaran yang diberikan di tingkat dasar pendidikan seni rupa maupun desain, yang diawali dari apa yang dilakukan Josef Albers dan Lazlo Maholy Nagy di pendidikan dasar untuk menghasilkan produksi massal (Masri \& Pasaribu, 2018). Pendekatan ini pun akhirnya menjadi doktrin bagi pendidikan desain pada umumnya. Bahkan doktrin ini didukung oleh Inna Alesina dan Elle Lupton pada bukunya, "Exploring Material" yang mengatakan bahwa material-material ini memperkaya pembendaharaan desain dan banyak solusi-solusi yang diperoleh dan diekspresikan. Bahkan pendekatan eksplorasi material ini digunakan sebagai upaya mendapatkan peluang baru dalam menghasilkan sebuah karya desain. Ada beberapa tahapan pendekatan ekspolasi material, diantaranya adalah (1) tahap pertama: pengenalan material; (2) tahap kedua: eksperimen lanjutan; (3) tahap ketiga: evaluasi alternatif; (4) tahap keempat: optimalisasi dimensi dan struktur; dan (5) tahap kelima studi detail desain (Masri \& Pasaribu, 2018).

Dari tahapan-tahapan di atas, terdapat kemiripan proses perancangan produk kostum oleh cosplayer dan cos-maker Indonesia dalam industri cosplay Indonesia dalam metode perancangan produk, yakni menggunakan tahapan pendekatan eksplorasi material. Dengan mengalami secara inderawi pada pendekatan fenomenologi terhadap studi proses perancangan produk kostum pada industri cosplay Indonesia, didapatkan sebuah kesimpulan bahwa dari pendekatan eksplorasi material pada dunia cosplay di Indonesia akhirnya melahirkan istilah kategori seperti kostum armor dan non-armor. Istilah ini didapat dari penggunaan material yang biasa digunakan oleh cosplayer dan cosmaker dalam merancang kostum cosplay. Umumnya kostum armor ini menggunakan material seperti busa hati atau istilah lainnya disebut eva foam sheet. Sementara untuk kostum non-armor biasanya menggunakan material kain dan sejenisnya.

Tak hanya itu saja, material utama yang digunakan cosplayer untuk membuat kostum cosplay biasanya dalam satu karakter dua dimensi bernaratif pada sebuah film, anime, manga, ataupun video game sekalipun, cosplayer sering memadu-padankan kedua kategori kostum tersebut tergantung dari karakternya. Bahkan kadang mereka pun membeli material seperti manik-manik ataupun bagian pelengkap kostum karakter yang sudah terdapat di pasar material sebagai bagian dalam proses perancangan kostum. Namun sayangnya tidak semua material atau bagian kostum dapat disediakan dengan mudah oleh pasar material. Para cosplayer maupun cosmaker harus membuat bagian dari kostum itu sendiri dengan membuat cetakan atau pun pola terlebih dahulu lengkap dengan 
motif yang digunakan, barulah kemudian mereka memproduksi menggunakan teknik cetak tuang agar dapat diproduksi lebih banyak.

Pada tahapan keempat pendekatan eksplorasi material ini, terjadi pengolahan teknik terhadap material yang digunakan. Semuanya itu tergantung dari karakter dua dimensi yang akan dibuat kostum dan perlengkapannya sehingga terlihat nampak nyata visual tiga dimensi bagi yang melihatnya. Salah satu campur tangan teknik dengan menggunakan teknologi terbaru di dunia cosplay adalah keberadaan teknik 3D printing.

Keberadaan teknik 3D printing ini merupakan alternatif proses pengerjaan dalam metode perancangan produk kostum di industri cosplay Indonesia sendiri terutama pada tahapan eksplorasi material. Hal itu karena pada umumnya produk kostum pada dunia industri cosplay Indonesia terdiri dari produk massal dan custom. Biasanya dalam proses perancangannya, cosmaker atau cosplayer membuat produk kostum ini dengan cara yang manual dan material yang ada. Teknik ini memiliki kelemahan jika diterapkan untuk dalam jumlah massal ataupun pesanan selanjutnya terutama dalam hal ukuran yang tidak presisi dan tidak sama. Sementara dengan adanya teknik 3D printing ini, para cosmaker terbantu dalam memproduksi kostum dengan ukuran yang sama dan massal baik itu untuk kategori kostum armor maupun non-armor dan baik secara keseluruhan maupun sebagai bagian pendukung atau pelengkap dari kostum tersebut.

\section{Kesimpulan}

Hasil penelitian terhadap metode perancangan kostum dalam industri cosplay Indonesia telah membuktikan peran 3D printing sebagai bagian dalam pembelajaran metode perancangan produk kostum. Meskipun pada metode perancangan kostum pada industri cosplay Indonesia, cosplayer atau cosmaker menggabungkan dua objek yang dilakukan dengan mimesis, yakni dengan meniru seutuhnya dari objek yang dipinjam, tapi dengan adanya rasa ingin tampil pada acara cosplay setiap tahunnya yang membuat semakin meningkatnya cosplayer Indonesia, membuat cosplay Indonesia berkembang dari pertunjukan seni wisata menjadi industri. Bahkan dari fenomena ini pun terdapat sebuah kebutuhan akan sebuah produk. Oleh karena itulah, lahirnya cosmaker pada komunitas cosplay Indonesia membuka peluang jasa pembuatan kostum cosplay dengan tujuan mempermudah konsumen atau klien untuk mendapatkan kostum dalam acara cosplay.
Metode perancangan kostum yang diterapkan oleh para cosplayer atau cosmaker pun memiliki tahapan yang mirip dengan metode perancangan produk pada umumnya. Hal ini terlihat dari tahapan eksplorasi material. Cosplayer atau cosmaker pun yang merancang sebuah kostum yang berasal dari karakter dua dimensi bernarasi pun harus memahami proporsi karena karakter dua dimensi ini pun memiliki proporsi yang berbeda dengan anatomi tubuh manusia. Kemudian selanjutnya pun mereka harus memiliki pengalaman dalam hal penguasaan dan pemahaman material. Oleh karena itu mereka harus melakukan eksplorasi material dengan mencoba material untuk menemukan kelemahan dan kelebihan material tersebut sehingga nantinya dapat dikombinasikan dengan material yang berbeda dalam proses perancangan. Didalam eksplorasi material ini pun terdapat penggunaan beberapa teknik. Salah satu teknik yang ada dalam industri cosplay Indonesia adalah 3D printing. Teknik ini dalam industri cosplay di luar negeri sudah umum dan biasa digunakan oleh para cosplayer.

Kelebihan 3D printing pada metode perancangan kostum industri cosplay Indonesia adalah hasilnya yang presisi sesuai dengan bentuk dua dimensi. Sayangnya teknik ini masih memiliki kekurangan karena dari harga mesin 3D printing masih mahal dan kurangnya ketersediaan filament di pasaran sehingga tidak banyak cosmaker atau cosplayer Indonesia yang menggunakannya. Padahal dari keunggulan lain 3D printing ini pada metode perancangan kostum industri adalah hasil jadinya bisa digunakan sebagai pemodelan awal agar dapat dijadikan bahan cetakan untuk dapat diproduksi secara massal. Meskipun demikian 3D printing tetap bisa dijadikan pembelajaran pada metode perancangan produk kostum, apalagi setelah melihat persamaan proses metode perancangan produk kostum pada pendidikan dasar desain dengan metode perancangan kostum pada industri cosplay Indonesia. Diharapkan dengan mempelajari 3D printing ini dapat dijadikan sebagai bekal pengetahuan untuk mendukung kreativitas dalam metode perancangan produk kostum.

\section{Daftar pustaka}

Abercrombie, A. (2015). Performance Costume Design at the New York Public Library for Performing Arts. New York: New York Public Library.

Akmal. (2019). Lebih Dekat dengan Industri 4.0. Yogyakarta: Deepublish Publisher.

Masri, A., \& Pasaribu, Y. M. (Eds.). (2018). Craft dan Desain di Indonesia: Sudut Pandang Akademik dan Pelaku. Bandung: Penerbit Aliansi Desainer Produk 
Industri Indonesia (ADPII).

Orsini, L. (2015). Cosplay: The Fantasy World of Role Play. London: Carlton Books.

Travers-Spencer, S., \& Zaman, Z. (2008). The Fashion Designer's Directory of Shape and Style. New York: Barrons Educational Series.
Widyastuti, P. A., Pertiwi, R., \& Huddiansyah, H. (2019). Peran Digitalisasi dalam Fenomena Perubahan Produk Cosplay Buatan Cosmaker pada Industri Cosplay Indonesia. In SENADA (Seminar Nasional Desain Dan Arsitektur) (Vol. 2, pp. 272-278). Denpasar. 